\title{
Progress in international geopolitical research from 1996 to 2015
}

\author{
SONG Tao ${ }^{1,2}$, LU Dadao ${ }^{1,2}$, LIANG Yi ${ }^{1,3}$, WANG Qian ${ }^{1,3}$, LIN Jing ${ }^{1,3}$ \\ 1. Institute of Geographic Sciences and Natural Resource Research, CAS, Beijing 100101, China; \\ 2. The Collaborative Innovation Center of the Geographical Environment and Frontier Development in South- \\ west China, Kunming 650500, China; \\ 3. University of Chinese Academy of Sciences, Beijing 100049, China
}

\begin{abstract}
Focusing on international relations from the perspective of geography, geopolitics exerts powerful influences on the course of economic and political development in the world. In the tide of globalization and information technology, geopolitics has become an important subject for global pattern interpretation and policy making. It is essentially important to have a scientific and systematic review on international geopolitics to promote its development. Based on the bibliometric statistics, the paper reviews the research development of geopolitics on the Web of Science from 1996 to 2015. The history, journals, papers and key research areas of geopolitics have been revealed in the paper. By the analysis of bibliometric statistics, the number of papers recently published in the journals of political geography and related geography journals continues to increase. The key areas of geopolitical papers which are globally highly cited include geopolitical interpretation of the countries and borders, critical geopolitics, emotional geopolitics, feminist geopolitics and other topics. Before the year of 2000 , the state and borders were hot topics of the geopolitical research. Yet since 2000, it has been the trend that the geopolitics is increasingly set in the context of geographical implications. At the same time, critical geopolitics appears to be the main area of geopolitical research, especially transitioning from traditional geopolitics towards the humanism-embeddedness (such as emotional geopolitics, feminist geopolitics). The paper then systematically reviews the branch trends of geopolitical research, including the borders and the territory, global geo-culture and geo-economics, Chinese models of geopolitics, resource conflicts and ecological politics, as well as emotional geopolitics. Finally, it puts forward the implication that Chinese geopolitical studies should reinforce the importance of geographical space and scale, use the process of description and multiple methods, as well as integrate humanistic thoughts, in order to further enrich the theories and practices of geopolitical research.
\end{abstract}

Keywords: geopolitics; discipline development; scientometrics; international research progress

Received: 2016-03-28 Accepted: 2016-05-30

Foundation: National Natural Science Foundation of China, No.41530634, No.41530751

Author: Song Tao (1983-), PhD, specialized in geopolitics and regional sustainable development.

E-mail: songtao@igsnrr.ac.cn 


\section{Introduction}

Geopolitics is a discipline which has made great contributions to national prosperity and safety (Du et al., 2015), whose research focuses on the process and trend of the relationship between different countries, regions, or nations by analyzing the formation of political and military alliance, union (political and military groups), political confrontation and containment, even war, based on the geographic location, space and historical-geographical factors ( $\mathrm{Lu}$ and $\mathrm{Du}, 2013$ ). During the period of great powers' early rising, Ratzel, Mahan and Kjellen were famous political geographers. During the period of imperial wars, Mackinder, Haushofer and Spykman became the master of the national geopolitical strategy. After that (the Cold War and the post Cold War Era), geopolitics was still a powerful and dynamic theoretical foundation for the development of great powers (Agnew et al., 2003). John Mearsheimer, Morgenthau, Cohen, Kaplan, Huntington, Henry Kissinger, Parker, Joseph Nye, Francis Fukuyama, Zbigniew Brzezinski and other modern geopolitical scholars, followed the idea of studying the global geopolitical pattern from the geographical space, but emphasized the impact of regions on the global geo-pattern in the context of realism, as well as the deep impacts of geo-economy and geo-culture on the global geo-structure.

Profound changes are taking place in the current global geopolitical world (Bellamy and Williams, 2011). With the rise of China (and other Asian countries), the relative decline of the United States and European Union, the status and relationships among global powers or regional powers are being remodeled. In particular, the rapid rise of China is changing the existing power structure of the world. The "Belt and Road Initiative" proposed by China reflects its courage and responsibility as a world power to actively participate in the construction of a new world order in terms of fairness, openness and justice. At the same time, main countries in the world have also adapted or developed new global geo-strategies, such as "Return to the Asia-Pacific" and "TTIP" strategies put forward by the United States. While the security of surrounding environment of China is being tightened by those gradually escalating disputes in South China Sea and Diaoyu Islands, these external space effects are caused by the rise of China ( $\mathrm{Lu}$ and $\mathrm{Du}, 2013$ ). Under these new geopolitical circumstances, it is urgent to comprehensively review the progress of international geo-political studies and build up Chinese geopolitical research vision. In doing so, Chinese scholars may realize the profound transformation of geo-strategies and predict the trend of geopolitics. Therefore, the aim of this paper is to review the international geopolitical research in the past 20 years, trace the evolutional characteristics of the global geo-relationship, as well as shed some light on Chinese geopolitical research.

\section{General situation of geopolitical research}

\subsection{Data and methods}

This paper analyzes the data from Web of Science, with the application of Histcite scientific measurement software. Histcite is a citation-analysis software, developed by the founder of the Science Citation Index - Garfield, which reviews the development history of a field by identifying key documents and graphs (Liu et al., 2014). In March 2015, 1001 papers in English since 1996 to 2015 were collected in Web of Science by defining "Geography" as 
the research direction, "Geopolitics" as the key subject word. By classifying and summarizing the titles, abstracts and key words of the articles, a systematic reflection on the latest research progress of the international geopolitics is displayed.

\subsection{Main journals}

On the whole, the number of geopolitical-related articles published in the journals of geography is increasing, as shown in Figure 1. Especially after the financial crisis in 2008, geographers have been paying more attention to the importance of geopolitical factors in the context of globalization. Papers were mainly published in Political Geography, Geopolitics, Annals of the Association of American Geographers, Progress in Human Geography, Environment and Planning-D, Eurasian Geography and Economics, Transactions of the Institute of British Geographers, Antipode, Geoforum, Area and other journals, as shown in Figure 2.

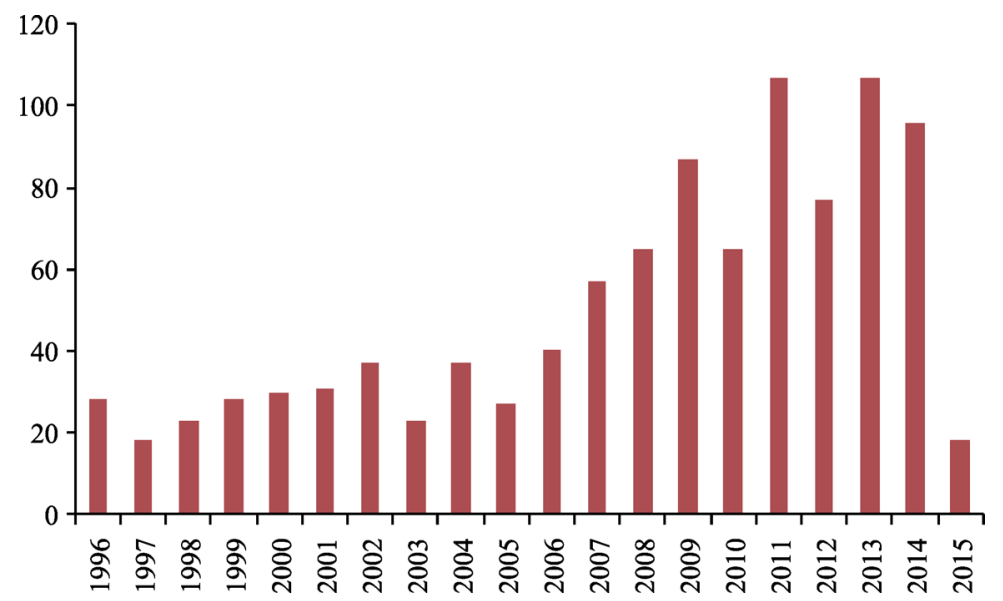

Figure 1 Number of geopolitical articles published in the international journals from 1996 to 2015

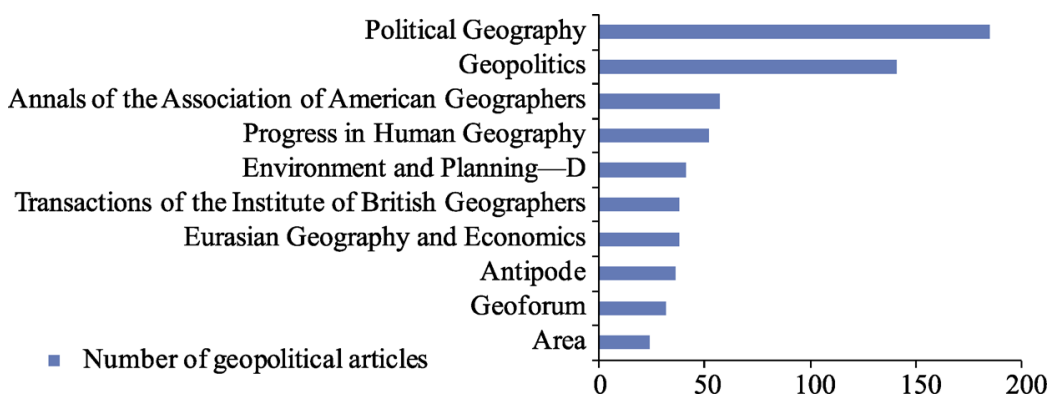

Figure 2 The top 10 journals with most geopolitical articles from 1996 to 2015

\subsection{Papers highly cited}

It is found that top 10 articles cited in the international journals from 1996 to 2015 focus on national geopolitical interpretation, border area development, critical geopolitics, emotional geopolitics, feminist geopolitics and other themes (see Table 1). When studying the literatures in different periods, the results are as follows: Before 2000, nations and borders were 
the core topics of geopolitical research. After 2000, the importance of geography has gradually further emphasized on geopolitics, which also turns to critical geopolitics, especially by reflection on the shift from traditional geopolitics towards more humanism-embeddedness (emotional geopolitics, feminist geopolitics, etc).

Table 1 Top 10 geopolitical articles cited in the international journals from 1996 to 2015

\begin{tabular}{|c|c|c|c|c|c|c|}
\hline Author & Year & Journal & $\begin{array}{l}\text { Citation } \\
\text { frequency }\end{array}$ & Theme & Title & Reference \\
\hline $\begin{array}{l}\text { Newman } \\
\text { and Paasi }\end{array}$ & 1998 & $\begin{array}{l}\text { Progress in Human } \\
\text { Geography }\end{array}$ & 180 & Border & $\begin{array}{l}\text { Fences and neighbours } \\
\text { in the postmodern } \\
\text { world: Boundary } \\
\text { narratives in political } \\
\text { geography }\end{array}$ & $\begin{array}{l}\text { (Newman and } \\
\text { Paasi, 1998) }\end{array}$ \\
\hline Pile & 2010 & $\begin{array}{l}\text { Transactions of the } \\
\text { Institute of British } \\
\text { Geographers }\end{array}$ & 136 & $\begin{array}{l}\text { Emotional } \\
\text { geopolitics }\end{array}$ & $\begin{array}{l}\text { Emotions and affect in } \\
\text { recent human geogra- } \\
\text { phy }\end{array}$ & (Pile, 2010) \\
\hline Sparke & 1998 & $\begin{array}{l}\text { Annals of the } \\
\text { Association of } \\
\text { American } \\
\text { Geographers }\end{array}$ & 95 & Countries & $\begin{array}{l}\text { A map that roared and } \\
\text { an original atlas: Can- } \\
\text { ada, cartography, and } \\
\text { the narration of nation }\end{array}$ & (Sparke, 1998) \\
\hline Sidaway & 2000 & $\begin{array}{l}\text { Progress in Human } \\
\text { Geography }\end{array}$ & 82 & $\begin{array}{l}\text { Critical } \\
\text { geopolitics }\end{array}$ & $\begin{array}{l}\text { Postcolonial geogra- } \\
\text { phies: An exploratory } \\
\text { essay }\end{array}$ & (Sidaway, 2000) \\
\hline Hyndman & 2004 & Political Geography & 80 & $\begin{array}{l}\text { Feminist } \\
\text { geopolitics }\end{array}$ & $\begin{array}{l}\text { Mind the gap: Bridging } \\
\text { feminist and political } \\
\text { geography through } \\
\text { geopolitics }\end{array}$ & $\begin{array}{l}\text { (Hyndman, } \\
\text { 2004) }\end{array}$ \\
\hline While & 2004 & $\begin{array}{l}\text { International } \\
\text { Journal of Urban } \\
\text { and Regional } \\
\text { Research }\end{array}$ & 79 & $\begin{array}{l}\text { Regional } \\
\text { Governance }\end{array}$ & $\begin{array}{l}\text { The environment and } \\
\text { the entrepreneurial city: } \\
\text { Searching for the urban } \\
\text { 'sustainability fix' in } \\
\text { Manchester and Leeds }\end{array}$ & $\begin{array}{l}\text { (Aidan et al., } \\
\text { 2004) }\end{array}$ \\
\hline Coleman & 2007 & Antipode & 73 & Border & $\begin{array}{l}\text { Immigration geopolitics } \\
\text { beyond the Mexico-US } \\
\text { border }\end{array}$ & (Coleman, 2007) \\
\hline Pain & 2009 & $\begin{array}{l}\text { Progress in Human } \\
\text { Geography }\end{array}$ & 69 & $\begin{array}{l}\text { Emotional } \\
\text { geopolitics }\end{array}$ & $\begin{array}{l}\text { Globalized fear? } \\
\text { Towards an emotional } \\
\text { geopolitics }\end{array}$ & (Pain, 2009) \\
\hline Hyndman & 2001 & $\begin{array}{l}\text { Canadian } \\
\text { Geographer }\end{array}$ & 68 & $\begin{array}{l}\text { Feminist } \\
\text { geopolitics }\end{array}$ & $\begin{array}{l}\text { Towards a feminist } \\
\text { geopolitics }\end{array}$ & $\begin{array}{l}\text { (Hyndman, } \\
\text { 2001) }\end{array}$ \\
\hline Roberts & 2003 & Antipode & 62 & $\begin{array}{l}\text { Neoliberal } \\
\text { geopolitics }\end{array}$ & Neoliberal geopolitics & $\begin{array}{l}\text { (Roberts et al., } \\
\text { 2003) }\end{array}$ \\
\hline
\end{tabular}

\section{The research fields of geopolitics}

According to the top 10 geopolitical papers highly cited each year since 1996, this paper summarized the trend of the international geopolitical research, as shown in Table 2. Proportion refers to the percentage of papers on each specific research field in all geopolitical journals since 1996. The research fields include border and territory, globalization and geo-culture, geo-economy, geopolitical hotspot areas and Chinese model, resource conflicts and ecological politics, as well as the value, emotion and cultural geography. 
Table 2 Research fields in international geopolitics

\begin{tabular}{|c|c|c|}
\hline Research direction & Research tendency & Proportion (\%) \\
\hline Border and territory & $\begin{array}{l}\text { Border security, the development of border areas, cross-border coop- } \\
\text { eration, geopolitical narrative of territory, discourse of the territory, } \\
\text { environmental determinism, map and drawing }\end{array}$ & 16.7 \\
\hline $\begin{array}{l}\text { Globalization and } \\
\text { geo-culture, } \\
\text { geo-economy }\end{array}$ & $\begin{array}{l}\text { Geo-economy, geo-culture, globalization and population migration, } \\
\text { geo-effect of information technology, popular geopolitics, foreign } \\
\text { investment, network, regional integration, ocean shipping }\end{array}$ & 14.5 \\
\hline $\begin{array}{l}\text { Geopolitical hot spot } \\
\text { areas and Chinese } \\
\text { model }\end{array}$ & $\begin{array}{l}\text { European Union, Southeast Asia, Afghanistan, Russia, Iran, foreign } \\
\text { policy, India, Arctic, North Korea, China threat theory, Central Asia }\end{array}$ & 21.1 \\
\hline $\begin{array}{l}\text { Resource conflicts and } \\
\text { ecological politics }\end{array}$ & $\begin{array}{l}\text { Petroleum, natural gas, cross-boundary river governance, dams, fish- } \\
\text { eries, international negotiations, global climate change, environmental } \\
\text { geopolitics }\end{array}$ & 19.9 \\
\hline $\begin{array}{l}\text { Value, emotion and } \\
\text { cultural geography }\end{array}$ & $\begin{array}{l}\text { Critical geopolitics, feminism of geopolitics, religion, narrative mode, } \\
\text { geopolitical environment, ethnicity, cultural geography, Confucian- } \\
\text { ism, identity, popular culture }\end{array}$ & 18.9 \\
\hline Others & $\begin{array}{l}\text { Liberal geopolitics, the marginal zone, the third world, the Eurasian } \\
\text { hinterland, governance, radical geopolitics, the fault zone, the } \\
\text { state-owned enterprises }\end{array}$ & 8.9 \\
\hline
\end{tabular}

\subsection{Border and territory}

Border is the interactive space of the territory. It covers a wide range of topics, mainly including: 1) the "disappearance" of boundaries and deconstruction of the territory in the context of globalization; 2) the role of the border in the construction of social identity; 3) characterization, narrative and construction of the border at different spatial scales. Under the influence of globalization, the border has become an important node of cross-border cooperation. The cheap land and available labor will facilitate cross-border cooperation in the border towns of less developed countries (Sit, 1998). However, due to the different interests of cross-border countries, the process of such cooperation often does not go well. The differences of institutional and cultural backgrounds increase the difficulties of cross-border cooperation (Paul, 2006). Due to the lack of bottom-up cooperation mechanisms, cities in growth triangle of Asia tend to develop independently rather than cooperate in an integrated way (Ishima et al., 1999), thus making them far lagging behind Europe and North America in terms of cross-border integration (Bunnell et al., 2006).

Border region is a place of cultural communication, in which the social identities of the border residents will be constructed. In border cities, twin cities are those cities characterized by locations across the border between the two countries, with shared urban hinterland and residents' senses of belongingness (Ehlers and Buursink, 2000). Research on twin cities emphasized on the integration of two cross-border cities in the economic, institutional and social aspects (Perkmann, 2003). The integration is composed of four gradations: the integration of the built-up area, the integration of behavior, the integration of organization, and the integration of politics and management (Buursink, 1996). This model might serve as a tool to analyze the characteristics of integration of the cross-border cities (Shen, 2013). As for the development stages of twin cities: Hong Kong and Shenzhen, it is revealed that economic integration prevails in the Hong Kong-Shenzhen integrated region. Economic integration has necessitated the institutional integration which in turn attempts to facilitate eco- 
nomic integration. However, it is still difficult to achieve the social and governance integration (Shen, 2014). In order to promote the free trade, the real demand for cross-border transnational governance is particularly prominent in twin cities (Sparke, 1998).

There are three kinds of interdependent and interactive spaces in border regions: conceived, perceived and lived spaces (Dean, 2005). In the case of Sino-Burmese border space, conceived space comprises the normative forms of spatial knowledge - the mental images promoted by territorial power. Perceived space is formed by the cross-border trade. Lived space is based on the cross-border marriage and cultural communication. The discordance among these three kinds of spaces makes the border region trapped in the challenging modernist dualism. Ethnographic participant observation could be used to address these problems in border research. This is demonstrated by a case study of the impact of the partial closure in 1999-2000 of the Uzbekistane Kyrgyzstan border in the Fergana Basin (Buursink, 1996). Research on the ethnic space of this border region informs a critique of state violence that is parallel to textual analyses informed by a critical border theory.

\subsection{Globalization and geo-culture, geo-economy}

Globalization is the process of deterritory, with national sovereignty deeply embedded in the neoliberal environment (Woodward, 2004). However, globalization has not prevailed over geography. Instead, based on the geographical environment, globalization adjusts itself and changes the environment accordingly. Flows of capital and manufacturing outsourcing factories flow into all parts of the world unequally. Their direction of movement is towards coastal countries and regions which are the main markets on a global scale with plenty of skilled labor force with learning capacity yet at inexpensive cost. With the injection of capital and information flows, concerns on border conflicts have been weakened, due to the fact that border land grows to the new core area of capital markets and business activities (Ohmae, 1995).

In the context of globalization, the new media technology, with great geopolitical significance, is recasting geo-cultural and geo-economic industries. This makes the structural relationship between the geopolitics and new media transit radically from the visual representation of the social sphere to social reconstruction and remodeling of geopolitical vision transition (Campbell, 2007). Worldwide trends in the information age will lead to a new paradigm of contemporary geopolitical transition, which is a paradigm for dialogues between different civilizations and different countries. Mutual development of globalization and regionalization will further strengthen the dialogue among civilizations, and gradually build up a global super civilization (Lilov, 2007). As Samuel Huntington (1993) proposed, people's cultural and religious identities will be the primary source of conflict in the post-Cold War world (Huntington, 1993). The population explosion in Muslim countries and the economic rise of East Asia are changing global politics. These developments challenge Western dominance, promote opposition to supposedly "universal" Western ideals, and intensify inter-civilization conflicts over such issues as nuclear proliferation, immigration, human rights, and democracy. People respond to the clash of civilizations by a variety of reactions, including novelty, indignation and confusion, published in the "Conflict and World Order of Civilizations and the Remaking" (Huntington, 2010). Besides the geo-culture, the geo-economics is a hot topic in geopolitics. State power will be re-interpreted, not only in 
the strategic and security as the only content, but also in the "connotation of geo-economics". Geo-economics is the study of spatial cultural and strategic aspects of resources, with the aim of gaining a sustainable competitive advantage, including geo-economic defense, geo-economic offensive and geo-economic diplomacy intelligence (Luttwak, 1993).

\subsection{Geopolitical hot spot areas and Chinese model}

Research on global hot spot areas by classical geopolitical theory is also an important part of geopolitical studies. In the process of European integration, such crises exist as trade and currency between the United Kingdom and the European Union, NATO's enlargement, the Greek debt, TTIP, Russia - Ukraine, etc. Kuus (2004) explained the geopolitical significance of EU and NATO's enlargement in the perspective of the dichotomy between Europe and Eastern Europe. Solovyev (2004) discussed the new post-Soviet Eurasian doctrine and geopolitical revisionist tendencies in Russia. Traditionalism is inspired by old European and Russian geopolitical theories. The revisionist school, on the other hand, adopts a considerably broader definition of what constitutes geopolitics by proposing to study various forms of organizing spaces on a global scale. Due to deep divisions among peoples and the sovereignty of countries, while heavily influenced by Great Power Politics, Shattered areas in the Middle East have long been geopolitical research hotspots, such as Iraq, Afghanistan, Iran and other countries. Scholvin (2011) deconstructs the ideological transition from a geopolitical perspective by the history of Iraq from the First World War to the 1958 revolution, including the Ottoman Empire, Arab nationalism, British imperialism, as well as the national autonomy. Hot geopolitical issues related to America include the US-Canada border Free Trade Zone (FTZ), the United States-Mexico border, etc. As the major core regions wrestling around the world, South Asia, Southeast Asia, Northeast Asia and Central Asian countries are becoming key areas of current geopolitical thinking. The level of economic development of these countries varies, with fragmented political systems and different ideologies. In such geopolitical core areas, India-Pakistan conflict (Aidan et al., 2004), cross-border development (Eilenberg, 2012), national division (Glassman, 2005), South China Sea issues, unrests in northern Myanmar, geo-energy issues (Pandian, 2005) are focus of the global geopolitics.

From a critical geopolitical perspective, China is regarded as a long-term rising global power (Kennedy, 1988), which is a sovereign territory within the boundaries, also a "geo-body" with no boundaries (Callahan, 2009). China has a unique historical process - the feudal imperial dynasty in history, and communism worldwide with rejection of capitalism, which shaped China's unique culture among the world's major powers (Keith, 2009). With a huge population, China has been subjected to humiliation in history, rather than conquest. These elements affect Chinese diplomatic policies and perceptions on China from the outside world. Chinese intellectuals learned a lot from American pluralistic diplomatic strategies, by transiting from neoliberal (rational actors who want to maximize the relative benefits of national action) to new realism (depending on the benefits from zero-sum game). According to Deng Xiaoping's "Theory of Chinese Characteristics", China will protect its sovereignty, take the principle of peaceful coexistence with other countries, as well as solve geopolitical problems by Chinese philosophy, language and expression. In the geopolitical relations with neighboring countries, the concept of "benevolent" in the Confucianism is the 
key principle to resolve the conflicts, instead of relying on the force. Interests rather than morality, is the base for geopolitical cooperation between different countries.

\subsection{Resource conflicts and ecological politics}

The exploitation of strategic resources, such as oil, water, etc. which are highly related to people's livelihood, is the hot topic in geopolitical studies. The production and consumption of global energy, affected by reserves, mining technology and other factors, are the competing interests of geopolitical game between countries. From the geopolitical perspective, nuclear energy in North Africa is likely to be seen with international skepticism, especially for energy exporting countries such as Algeria, Libya, and Egypt. Given their current political power structures and geopolitical constellations, such as the presence of non-democratic regimes and the Arab-Israeli conflict, the adoption of nuclear energy production technologies has the potential to cement the prevailing regime fundamentals. Energy importers such as Morocco and Tunisia enjoy greater credibility if they opt for the use of nuclear energy as a source of economic development (Marktanner and Salman, 2011). Verma (2007) analyzed the importance of Iran-Pakistan-India gas pipeline for India in geopolitical energy security and economic sustainable development (Verma, 2007).

Ecological degradation is one of the key challenges for geopolitics in the new millennium, especially in dealing with tension between the exploitation of natural resources and political regulation on ecological protection under the sustainable development goal (Beier, 1998). As an important strategic ecological resource, water plays an important role in the international geopolitical pattern. For the cross-border co-governance on water resources, hot issues discussed include the improvement of international hydro-graphic cooperation efficiency (Wolf, 1999), geopolitical strategies of international basin (Brichieri-Colombi and Bradnock, 2003), adaptive mechanism of multilateral basin (Shmueli, 1999), as well as multinational governance on international water conflicts (Feitelson, 2002). Taking the Mekong River as an example, the Mekong River is a "commercial corridor", instead of a geopolitical "frontier" during the Cold War times. Six countries along the Mekong River have endeavored to integrate economic, infrastructure and social development by multilateral and bilateral donors, loans, and other ways.

\subsection{Value, emotion and cultural geography}

Critical geopolitics is different from classic geopolitics, such as Mackinder's heartland theory (Mackinder, 2004), which focuses on how natural geographical factors influence the political decision-making. Critical geopolitics foregrounds the substantial work on intellectuals of statecraft, popular geopolitics, feminist geopolitics, and resistance or anti-geopolitics. As Taylor (2000) mentioned, geopolitical decoding referred to the perceived value of geopolitical dependencies among different areas. Self-recognitions of different crossborder groups are being marginalized in the globalization process, but still important in the local politics "from below" (Fluri, 2009). The term "from below" is applied to illustrate a dialogue platform beyond the power, domination and control in the public sphere, in which marginalized groups can have impacts on the decision making progress in civil society (Snyder, 2008). Drawing empirically from Central Europe and especially Estonia, intellectuals are central to the production of a particular 'cultural' concept of geopolitics - the no- 
tion that foreign policy expresses the state's and the nation's identity. Beyond Central Europe, it is underscored that the political and cultural milieu of geopolitical claims and the specific structures of legitimacy are from classic intellectuals (Kuus, 2007).

Cultures of fear, humiliation and hope are reshaping our world (Moysey, 2010). The terrorist attacks and local wars suffered by Western world in this century triggered a new round of geopolitical fears (Pain, 2009). In the traditional realist geopolitical strategy, to seek maximum security interests of the country, the emotion of fear caused by international conflicts is manipulated by politicians (Bleiker and Leet, 2006). Research on the fears is embedded in the geopolitical cultural, economic, social and spatial study. Early research on geopolitical fear focused on portray of prevailing shared fears in community citizens. After 2000 , the critical geopolitical research on feminist and other structuralism is increasingly important, shifting from personal emotions to emotions embedded in the complex social and political background (Lee, 2008). One of the contributions to the critical geopolitical research in the feminist geopolitics is to explore the space within the geopolitical dimension, including formal and informal political action (Secor, 2001), and should take into account the impact of gender politics and power (Hyndman, 2007). Feminist researchers emphasize the female daily impacts on the existing hierarchy of power. For example, the reproductive rights are an important component of geopolitical power (Martin, 2004).

\section{General research transformation of geopolitics}

Based on the specific research fields of geopolitics, this article systematically summarizes the macroscopic research interests of geopolitics after Cold War: (1) the establishment of the new world order in the post-Cold War era, (2) an emphasis on the spatial cognition, and (3) the rise of critical geopolitics which reviews conventional classical theories of geopolitics critically.

\subsection{Establishment of the new world order in the post-Cold War era}

From 1989 to 1991, the drastic changes in Eastern Europe, German reunification and collapse of the Soviet Union marked the end of Cold War. Consequently, geopolitics stepped into the post-Cold War era (Cohen, 2011). Geopolitics has gone through five phases of development since Ratzel presented the National Organism Theory: the struggle of empires, German geopolitics, geopolitics of the United States, the period of Cold War and the post-Cold War era (as shown in Table 3). The struggle of empires was a period in which Europe was the geopolitical center before the two world wars. In this phase, significant theories including National Organism, World Island, Heartland and Sea Power, reflected influences of Social Darwinism and the nation-state. With the support of Nazi Germany, Pan-continentalism became the core of geo-strategy in German geopolitics in which representative scholar was Haushofer. In US geopolitics field, Spykman's Rimland Theory guided the spatial arrangement of the US military and diplomatic strategy. The balance of powers and containment to opponents were advocated by realistic geopolitics during the period of Cold War (Wang, 2003) when numerous scholars proposed putting western forces into Central and Eastern Europe so as to weaken the geopolitical advantages of heartland in Russia's west. They also proposed permeating the Caucasus and Central Asia, and provoking China 
against Russia.

In the post-Cold-War era, geopolitics follows two research trends as the following: state-centrism-political and universalism-geographical paradigm. Geo-strategists such as Kissinger and Brzezinski, regarded the end of Cold War as establishment of the "new world order" and geopolitical pattern of the US-led global hegemony. After the Cold War, the political and economic pattern of unipolar world and unilateralism were entirely changed by the rise of emerging Third World countries such as China, the enlargement of European Union, as well as economic globalization and global climate change since the mid-1990s (Mao, 2014). The world pattern of "one superpower and multi-great powers" is developing (Hu et al., 2013; Wang et al., 2012; Wang et al., 2014). "Vacuum" or "vulnerable" multipolar zones, including Central Asia, Asia-Pacific and the Arctic, are hot spot areas of geopolitical research (Du et al., 2015). Brzezinski, former assistant to the president of the United States for national security, proposed controlling three strategic areas in the grand Eurasian chessboard - Western Europe, the Middle East and East Asia for the US global domination in 1997. Samuel Huntington attributed geopolitical conflicts to "the clash of civilizations" (Huntington, 2010). Universal application of western liberalism and the fade of Marxism-Leninism indicate the coming appearance of a universal, homogeneous state system. Under this idealized worldview, geopolitical cooperation is the primary trend of geopolitics (Fukuyama, 1993). As economic globalization develops in depth, geopolitics exerts influences generally via geo-economics (Wang, 2003).

Table 3 Evolutionary phases of modern geopolitics

\begin{tabular}{|c|c|c|c|c|c|}
\hline & Phase one & Phase two & Phase three & Phase four & Phase five \\
\hline Phases & $\begin{array}{l}\text { Struggle of } \\
\text { empires }\end{array}$ & $\begin{array}{l}\text { German } \\
\text { geopolitics }\end{array}$ & $\begin{array}{l}\text { Geopolitics of the } \\
\text { United States }\end{array}$ & $\begin{array}{l}\text { Geopolitics dur- } \\
\text { ing Cold War }\end{array}$ & Post-Cold War era \\
\hline $\begin{array}{l}\text { Representa- } \\
\text { tive scholars }\end{array}$ & $\begin{array}{l}\text { Ratzel, Mackin- } \\
\text { der, Kjellen, } \\
\text { Bowman, Mahan }\end{array}$ & $\begin{array}{l}\text { Haushofer, } \\
\text { Maul, Banser }\end{array}$ & $\begin{array}{l}\text { Spykman, George } \\
\text { Reina, Seversky }\end{array}$ & $\begin{array}{l}\text { Kennan, Kiss- } \\
\text { inger, Brzezinski, } \\
\text { Taylor }\end{array}$ & $\begin{array}{l}\text { Fukuyama, Kap- } \\
\text { lan, Brzezinski, } \\
\text { Nye, Huntington, } \\
\text { Cohen }\end{array}$ \\
\hline $\begin{array}{l}\text { Representa- } \\
\text { tive view- } \\
\text { points }\end{array}$ & $\begin{array}{l}\text { National Organ- } \\
\text { ism, World Is- } \\
\text { land, Heartland, } \\
\text { Sea Power } \\
\text { Theory }\end{array}$ & $\begin{array}{l}\text { Pan-continent } \\
\text { alism }\end{array}$ & Rimland Theory & $\begin{array}{l}\text { Containment } \\
\text { strategy, balance } \\
\text { of power, overall } \\
\text { views }\end{array}$ & $\begin{array}{l}\text { Universalistic } \\
\text { geopolitics, Criti- } \\
\text { cal geopolitics, } \\
\text { State-centrism, } \\
\text { Clash of civiliza- } \\
\text { tions }\end{array}$ \\
\hline $\begin{array}{l}\text { Geopolitical } \\
\text { background }\end{array}$ & $\begin{array}{l}\text { German Empire } \\
\text { under the lead- } \\
\text { ership of Bis- } \\
\text { marck, World } \\
\text { War I }\end{array}$ & $\begin{array}{l}\text { Rise of Ger- } \\
\text { many after } \\
\text { World War I }\end{array}$ & $\begin{array}{l}\text { Rise of US during } \\
\text { and after World } \\
\text { War II }\end{array}$ & $\begin{array}{l}\text { US-Soviet con- } \\
\text { frontation }\end{array}$ & $\begin{array}{l}\text { Iraq War, the war } \\
\text { in Afghanistan, } \\
\text { counter-terrorism }\end{array}$ \\
\hline
\end{tabular}

Reference: Cohen, 2011

\subsection{Return of spatial significance in geopolitics}

With the innovation of science and technology continuously shortening the spatial distance, the significance of geography was once questioned by numerous scholars, but space has always been an essential factor (Kaplan, 2009). In the geopolitical conflicts occurring in "conventionally geopolitical shattered areas", such as the wars in Bosnia, Iraq and Afghanistan, contemporary information technology has been applied to ensure spatial and territorial 
integrity since the 1990s. Space and territory are yet regarded as significant, essentially crucial factors in foreign and military policy of the US (Ek, 2000). The significance of geography is not only reflected in military and political significance of strategy and tactics, territorial significance from the perspective of culture, but also spatial control and investigation of resources, population and material systems (Mao, 2014). The control of military affairs, politics, civilization, communications and population needs to be changed to respond to technical innovation and spatial reform in the context of globalization (Cohen, 1991). Geographic geopolitics emphasizes the analysis and interpretation of localization rather than globalization. The locality is complex, multiple and heterogeneous space, as well as aggregation of economics, society and environment, thus the "specificity" of localization demonstrating the significance of geography in geopolitics (Pleshakov, 1994). The key of pragmatically geopolitical research is to excavate the development conditions, structure and power of localization so as to mediate and resolve the international conflicts (Tuathail, 2010). The geopolitical research and practice which emphasize space and localization, are reflected in four levels: national geo-strategy formulated by state leaders and diplomats, geo-strategy proposed by numerous strategic research institutes including think-tanks and academia, differentiated geographic spaces of production, distribution and consumption presented by popular geopolitics, which is connected simultaneously through common geo-cultural areas (such as districts, states), as well as structural geopolitics which focuses on how progress, trends and contradictions of globalization affect contemporary geopolitical conditions and geopolitical practice (Kearns, 2010). In practice, the four types of geopolitics merge mutually (Tuathail, 1998), and jointly propel the return of spatial significance in geopolitics.

\subsection{Turning to critical geopolitics}

The major ideological trend of geopolitical research has been turning to "critical geopolitics" since the 1990s (Figure 3). "Critical" means the suspicion towards state-centrism, and "geopolitics" is closely associated with the alternation of power. Global contemporary politics is increasingly driven by such non-state actors as credit rating agencies, NGO and transnational corporations, so the definition of "critical geopolitics" is not only criticism towards state-centrism but also criticizing the traditional power-centered geopolitics. Critical geopolitics constitutes geopolitical cognition via associating visual images (especially maps) and words (political speeches, analogies and metaphors) with political manifestations (economic and political practice, such as currency and military deployment), so as to guide official foreign policy and facilitate adjustments of various organizations' strategic policies (Tuathail, 1999).

Different from conventional geopolitics which focuses on the key role of geography in political rights, critical geopolitics applies social-scientific critical thinking to inquire how power works and how it may be challenged (Agnew, 2001). Using inter-disciplinary theories and methods of sociology, GIS, culturology and semantics for references, critical geopolitics analyzes and emphasizes that class, race, gender and other hierarchy of capitalism continue to be the reality and need to be rebuilt in the changing geopolitical context (Agnew and John, 2003), which is reflected through discourse, rhetoric, metaphor and symbolism. Critical geopolitics analyzes geography of social movements which is related to feminism, radicalism and participatory democracy from the perspective of national security (Amin and Thrift, 
2005). It is also expounded that geopolitical issues via analyzing processes of non-political development and cooperation, by emphasizing discourse rights and participation processes of NGO, community and individual in geopolitical issues, such as Asian Development Bank and community residents in the Mekong sub-regional cooperation (Painter, 1995) .

In the geopolitical world under the influence of globalism, power will decentralize more universally and hierarchy will be weakened (Cohen, 2011). Global geopolitical maps and panoramic institutionalized strategic viewpoints will yet be the central issues of geopolitics. Under the influence of multiple factors including climate change, nation-states, NGO and religious relations, global geopolitical pattern will differ from the conventionally geopolitical perspectives characterized by the rivalry of powers and global demarcation of powers. Strategic balance of global powers and its approaches to implementation will be the latest trend of geo-strategic research (Wang et al., 2015). Critical thinking of geopolitics (Hu et al., 2015) has become a novel perspective of multiple research subjects including geopolitical processes and discourse rights, thus it is now making great strides forward to a promising tide of geopolitical research.

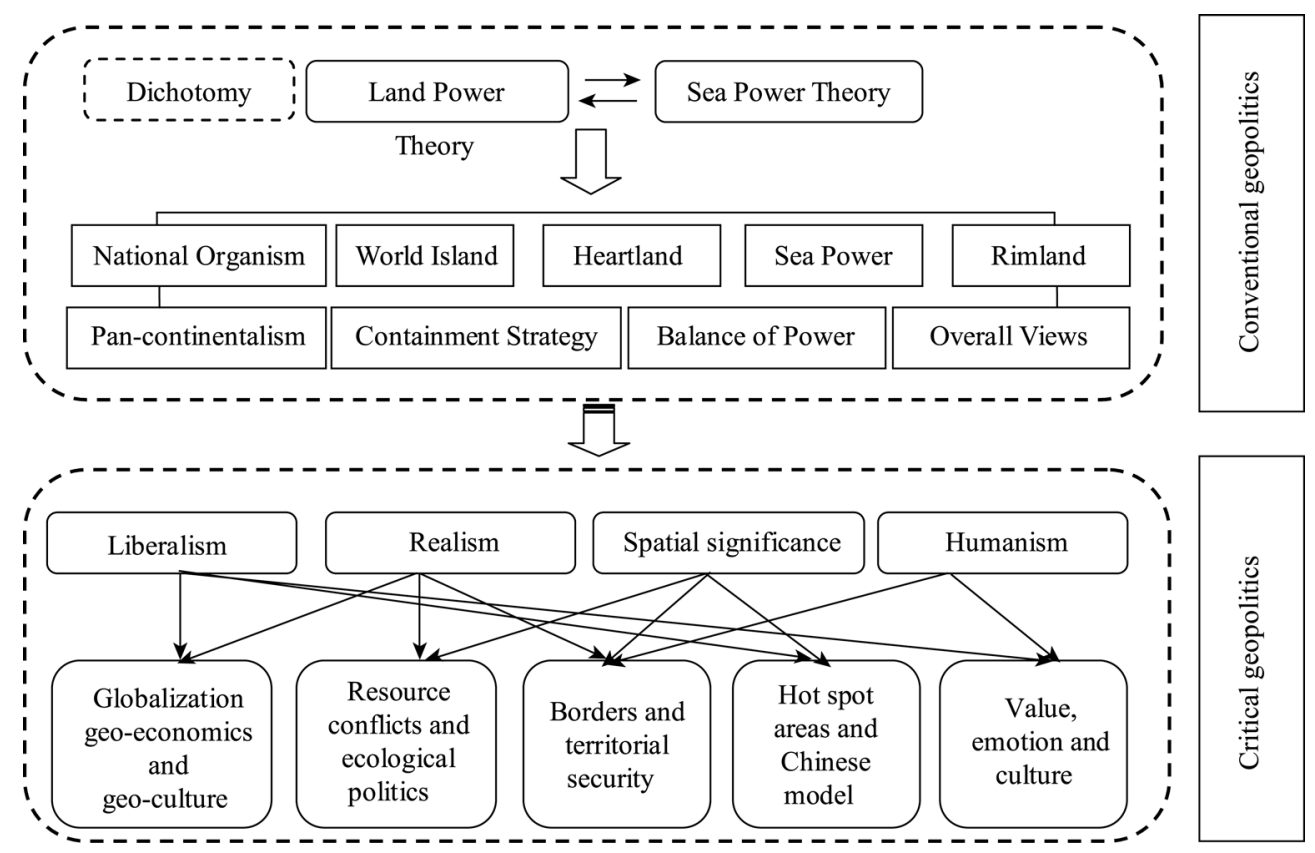

Figure 3 Trends of international research on geopolitics for the last 20 years

\section{Conclusion and outlook}

In the tide of globalization and informatization, the new profile of international arena begins to form, and geopolitics becomes a significant means for interpreting global pattern and formulating policy. Through systematically analyzing the research trends based on geopolitical articles in Web of Science from 1996 to 2015, this article concludes that: in the recent round of geopolitical research, the number of published geopolitical papers increases gradually. The main research perspective is a critical review of conventionally geopolitical theories, with the emphasis on the significance of geographic space, integration of in- 
ter-disciplinary research methods and humanistic factors. The discussion also covers such research fields as borders and territory, geo-economics, conflicts of resources and ecology, value and emotion. International research on geopolitics enlightens the revival of Chinese geopolitics:

(1) Research on China's geo-strategy after Cold War. In the era of "one superpower and multiple great powers" and under the premise of homeland security, communication and cooperation of geo-economics and geo-culture are the key themes. One of the primary missions of China's geographic research in the future is to innovate and apply geopolitical and geo-economic theories with Chinese characteristics on the basis of western geopolitical and geo-economic theories and the need of China's national security and peaceful rise during the new period (Mao, 2014).

(2) Intensification of space and scales. Although geographers' research on geopolitics experienced the revolutionary transformation of cognition on the relationship between human beings and geographical environment that human beings become "participants" of environment from being its "masters" (Sneddon and Fox, 2006), the significance of geospatial dimensions is strengthened in the latest geopolitical tide, in which space is yet the central carrier of military, economic and cultural development. Under diverse scales of globe, state, region and border, the spatial rationalization of geostrategic relationships deserves further consideration from geopoliticians, and the multilateral participation of governments, enterprises and academia ought to be emphasized.

(3) Narration, processes and multiple methods. Geopolitics, a significant sub-discipline of geography, needs to enhance cooperation with numerous disciplines including other branches of human geography, physical geography, GIS, international relations, sociology and politics. Methodologies of geopolitics ought to not only remain in the narration and discussion of physical geographic space, but also integrate multiple research methods such as spatial analysis of geography, semantics, symbolic imaginations and ethnology.

(4) The infusion of humanism. A major research trend of international geopolitics is the infusion of humanistic concepts and category. Chinese geopolitics needs to macroscopically explore geo-strategy from top to bottom and thoroughly analyze multiple subjects including residents, NGO and females from the bottom up. Research on humanistic background behind geopolitical phenomena should be paid more attention.

\section{References}

Agnew J, 1998. Geopolitics: Re-visioning World Politics. London and New York: Routledge.

Agnew J A, 2001. Disputing the nature of the international in political geography: The Hettner-Lecture in Human Geography. Geographische Zeitschrift, 89(1): 1-16.

Agnew J, 2010. Emerging China and critical geopolitics: Between world politics and Chinese particularity. Eurasian Geography and Economics, 51(5): 569-582.

Agnew J, Mitchell K, Toal G, et al., 2003. A Companion to Political Geography. Oxford: Blackwell.

Akiner S, 2004. Geopolitics of hydrocarbons in Central and Western Asia. In: Akiner S (ed.). The Caspian: Politics, Energy and Security. London: Routledge Curzon.

Amin A, Thrift N, 2005. What's left? Just the future. Antipode, 37(2): 220-238.

Bakker K, 1999. The politics of hydropower: Developing the Mekong. Political Geography, 18(2): $209-232$.

Barter P, 2006. Multiple dimensions in negotiating the cross-border transport links that connect and divide Sin- 
gapore and Johor, Malaysia. Asia Pacific Viewpoint, 47(2): 287-303.

Beier C, 1998. Dezentralisierung und Entwicklungs management in Indonesien. GeoJournal, 44(1): 92-93.

Bellamy A J, Williams P D, 2011. The new politics of protection? Cote d'Ivoire, Libya and the responsibility to protect. International Affairs, 87(4): 825-850.

Bleiker R, Leet M, 2006. From the sublime to the subliminal: Fear, awe and wonder in international politics. Journal of International Studies, 34(3): 713-737.

Brichieri-Colombi S, Bradnock R W, 2003. Geopolitics, water and development in South Asia: Cooperative development in the Ganges-Brahmaputra delta. The Geographical Journal, 169: 43-64.

Bunnell T, Muzaini H, Sidaway J D, 2006. Global city frontiers: Singapore's hinterland and the contested socio-political geographies of Bintan, Indonesia. International Journal of Urban and Regional Research, 31(1): $3-22$.

Buursink J, 1996. Becoming Twin Citizens in Minneapolis and St Paul: A Case of Territorial Integration // Davies R J. Contemporary City Structuring. Society of South African Geographers. Cape Town: IGU Commission on Urban Development and Urban Life.

Callahan W A, 2009. The cartography of national humiliation and the emergence of China's geobody. Public Culture, 21(1): 141-173.

Campbell D, 2007. Geopolitics and visuality: Sighting the Darfur conflict. Political Geography, 26(4): 357-382.

Cohen S B, 1991. Presidential address: Global geopolitical change in the post-cold era. Annals of the Association of American Geographers, 81(4): 551-580.

Cohen S B, 2011. Geopolitics: The Geography of International Relations. 2nd ed. Shanghai: Shanghai Academy of Social Sciences Press.

Coleman M, 2007. Immigration geopolitics beyond the Mexico-US border. Antipode, 39(1): 54-76.

Dean K, 2005. Spaces and territorialities on the Sino-Burmese boundary: China, Burmna and the Kachin. Political Geography, 24(7): 808-830.

Du Debin, Duan Dezhong, Liu Chengliang, et al., 2015. Progress of geopolitics of Chinese geography since 1990. Geographical Research, 34(2): 199-212. (in Chinese)

Ehlers N, Buursink J, 2000. Binational Cities: Peoples, Institutions, and Structures//M van der Velde, H van Houtum. Borders Regions and People. London: Pion, 182-201.

Eilenberg M, 2012. The confessions of a timber baron: patterns of patronage on the Indonesian-Malaysia border Identities. Global Studies in Culture and Power, 19(2): 149-167.

Ek R, 2000. A revolution in military geopolitics? Political Geography, 19(7): 841-874.

Feitelson E, 2002. Implications of shifts in the Israeli water discourse for Israeli-Palestinian water negotiations. Political Geography, 21(3): 293-318.

Fluri J L, 2009. Geopolitics of gender and violence 'from below'. Political Geography, 28(4): $259-265$.

Fukuyama F, 1992. The End of History and the Last Man? New York: Free Press, 199-208.

Glassman J, 2005. On the borders of Southeast Asia: Cold War geography and the construction of the other. Political Geography, 24(7): 784-807.

Grundy-Warr C, Peachey K, Perry M, 1999. Fragmented integration in the Singapore Indonesian border zone: Southeast Asia's "growth triangle" against the global economy. International Journal of Urban and Regional Research, 23(2): 304-328.

Hu Zhiding, Cao Yuan, Liu Yuli, Ge Yuanjing, 2013. A new development of political geography research in China: Geo-setting. Human Geography, 133(5): 123-128. (in Chinese)

Hu Zhiding, Lu Dadao, 2015. The re-interpretation of the classical geopolitical theories from a critical geopolitical perspective. Acta Geographica Sinica, 70(6): 851-863. (in Chinese)

Huntington S P, 1993. The clash of civilizations. Foreign Affairs, 72(3): 22-49.

Huntington S P, 2010. The Clash of Civilizations and the Remaking of World Order. Beijing: Xinhua Press.

Hyndman J, 2001. Towards a feminist geopolitics. Canadian Geographer, 45(2): 210-222.

Hyndman J, 2004. Mind the gap: Bridging feminist and political geography through geopolitics. Political Geography, 23(3): 307-322. 
Hyndman J, 2007. Feminist geopolitics revisited: Body counts in Iraq. Professional Geographer, 59(1): 35-46.

Kaplan R D, 2009. The revenge of geography. Foreign Policy, 5: 1-9.

Kearns G, 2010. Geography, geopolitics and Empire. Transactions of the Institute of British Geographers, 35(2):187-203.

Keith R C, 2009. China from the Inside Out: Fitting the People's Republic into the World. London: Pluto.

Kennedy P, 1986. The Rise and Fall of the Great Powers. New York: Basic Books.

Kuus M, 2004. Europe's eastern expansion and the reinscription of otherness in East-Central Europe. Progress in Human Geography, 28 (4): 472-489.

Kuus M, 2007. Intellectuals and geopolitics: The 'cultural politicians' of Central Europe. Geoforum, 38(2): 241-251.

Lee M, 2007. Inventing Fear of Crime: Criminology and the Politics of Anxiety. Cullompton: Willan Publishing.

Lilov A, 2007. The Dialogue of Civilizations: The World Geopolitical Trends. Beijing: Social Sciences Academic Press. (in Chinese)

Liu Zhigao, Wang Chen, Li Erling et al., 2014. Research progress of economic geography in China. Acta Geographica Sinica, 69(10): 1449 -1458. (in Chinese)

Lu Dadao, Du Debin, 2013. Some thoughts on the strengthening of geopolitical and geo-economic studies. Acta Geographica Sinica, 68(6): 723-727. (in Chinese)

Luttwak E N, 1993. The coming global war for economic power: There are no nice guys on the battlefield of geoeconomics. The International Economy, 7(5): 18-67.

Mackinder H J, 1904. The geographical pivot of history. Geographical Journal, 23(4): 422.

Mao Hanying, 2014. Geopolitical and geoeconomic situation in the surrounding areas and China's strategies. Progress in Geography. 33(3): 289-302. (in Chinese)

Marktanner M, Salman L, 2011. Economic and geopolitical dimensions of renewable vs. nuclear energy in North Africa. Energy Policy, 39(8): 4479-4489.

Martin P M, 2004. Contextualizing feminist political theory. In: Staeheli L, Kofman E, Peake L (ed.). Mapping Women, Making Politics: Feminist Perspectives on Political Geography. New York: Routledge.

Megoran N, 2006. For ethnography in political geography: Experiencing and re-imagining Ferghana Valley boundary closures. Political Geography, 25(6): 622-640.

Moysey D, 2010. The Geopolitics of emotion. Beijing: Xinhua Press. (in Chinese)

Newman D, Paasi A, 1998. Fences and neighbours in the postmodern world: Boundary narratives in political geography. Progress in Human Geography, 22(2): 186-207.

Ohmae K, 1995. China's 600,000 Avon ladies. New Perspectives Quarterly, 21(1): 14-20.

Pain R, 2009. Globalized fear? Towards an emotional geopolitics. Progress in Human Geography, 33(4): 466-486.

Painter J, 1995. Politics, Geography and Political Geography: A Critical Approach. London: Arnold.

Pandian S G, 2005. Energy trade as a confidence-building measure between India and Pakistan: A study of the Indo-Iran trans-Pakistan pipeline project. Contemporary South Asia, 14(3): 307-320.

Parker G, 2003. Geopolitics: Past, Present and Future. Beijing: Xinhua Press. (in Chinese)

Perkmann M, 2003. Cross-border regions in Europe: Significance and drivers of regional cross-border cooperation. European Urban and Regional Studies, 10(2): 153-171.

Pile, S, 2010. Emotions and affect in recent human geography. Transactions of the Institute of British Geographer, 35(1): 5-20.

Pleshakov K, 1994. Geopolitika v svete globalnykh peremen. Mezhdounarodnaya zhizn, 10: 30-39.

Roberts S, Secor A, Sparke M, 2003. Neoliberal geopolitics. Antipode, 35(5): 886-897.

Scholte J A, 2000. Globalisation: A Critical Introduction. Houndmills: Macmillan.

Scholvin S, 2011. Clashing geopolitical visions: Iraq from the first world war to the 1958 revolution. Revista Română de Geografie Politică, 2: 157-170.

Secor A, 2001. Toward a feminist counter-geopolitics: Gender, space and Islamist politics in Istanbul. Space and Polity, 5(3): 191-211. 
Shen J F, 2014. Not quite a twin city: Cross-boundary integration in Hong Kong and Shenzhen. Habitat International, 42: 138-146.

Shen Jianfa, 2013. Cross-boundary urban development and integration: A case study of Hong Kong and Shenzhen. City Planning Review, 37(6): 20-25. (in Chinese)

Shmueli D F, 1999. Water quality in international river basins. Political Geography, 18(4): 437-476.

Sidaway J D, 2000. Postcolonial geographies: An exploratory essay. Progress in Human Geography, 24(4): 591-612.

Sit V F S, 1998. Hong Kong's "transferred" industrialization and industrial geography. Asian Survey, 38(9): 880-904.

Sneddon C, Fox C, 2006. Rethinking transboundary waters: A critical hydropolitics of the Mekong basin. Political Geography, 25(2): 181-202.

Snyder K A, 2008. Building democracy from below: A case from rural Tanzania. Journal of Modern African Studies, 46(2): 287-304.

Solovyev E G, 2004. Geopolitics in Russia: Science or vocation? Communist and Post-Communist Studies, 37(1): 85-96.

Song X, 2001. Building international relations theory with Chinese characteristics. Journal of Contemporary China, 10(26): 61-74.

Sparke M, 1998. A map that roared and an original atlas: Canada, cartography, and the narration of nation. Annals of the Association of American Geographers, 88(3): 463-495.

Sparke M, 2008. From geopolitics to geoeconomics: Transnational state effects in the borderlands. Geopolitics, 3(2): 62-98.

Taylor P J, Flint C, 2000. Political Geography: World-Economy, Nation-State and Locality. 4th ed. London: Prentice Hall.

Tuathail G O, 2010. Localizing geopolitics: Disaggregating violence and return in conflict regions. Political Geography, 29(5): 256-265.

Tuathail G O, 1998. Postmodern geopolitics? The modern geopolitical imagination and beyond. In: Tuathail G O, Dalby S. Rethinking Geopolitics. London: Routledge.

Tuathail G O, 1999. Understanding critical geopolitics: Geopolitics and risk society. In: Gray C S, Sloan G. Geopolitics, Geography and Strategy. London: Cass.

Usher A D, 1997. Dams as Aid: A Political Anatomy of Nordic Development Thinking. London: Routledge.

Verma S K, 2007. Energy geopolitics and Iran-Pakistan-India gas pipeline. Energy Policy, 35(6): 3280-3301.

Wang Enyong, 2003. Political Geography. Beijing: Higher Education Press. (in Chinese)

Wang Limao, Li Hongqiang, Gu Mengchen, 2012. Influence path and effect of climate change on geopolitical pattern. Acta Geographica Sinica, 67(6): 853-863. (in Chinese)

Wang Shufang, Ge Yuejing, Liu Yuli, 2015. The spatio-temporal evolution and driving mechanism of geopolitical influence of China and the US in South Asia. Acta Geographica Sinica, 70(6): 864-878. (in Chinese)

Wang Wentao, Liu yanhua, Yu Hongyuan, 2014. The geopolitical pattern of global climate change and energy security issues. Acta Geographica Sinica, 69(9): 1259-1267. (in Chinese)

While A, Jonas A E G, Gibbs D, 2004. The environment and the entrepreneurial city: Searching for the urban 'sustainability fix' in Manchester and Leeds. International Journal of Urban and Regional Research, 28(3): 549-569.

Withers C W J, 2013. On enlightenment's margins: Geography, imperialism and mapping in Central Asia, c.1798-c.1838. Journal of Historical Geography, 39: 3-18.

Wolf A, 1999. Criteria for equitable allocations: The heart of international water conflict. Natural Resources Forum, 23: 23-30.

Woodward B, 2004. Plan of Attack. New York: Simon and Schuster. 